DOI 10. 18307/2015. 0606

(C) 2015 by Journal of Lake Sciences

\title{
安徽升金湖国家级自然保护区水鸟生境适宜性变化”
}

\author{
杨 李 ${ }^{1,2}$, 董 斌 ${ }^{* * *}$, 汪 庆 $^{1}$, 盛书薇 ${ }^{1}$, 韩文妍 ${ }^{2}$, 赵 俊 $^{1}$, 程明伟 ${ }^{2}$, 杨少文 ${ }^{1}$ \\ ( 1 : 安徽农业大学研究生院, 合肥 230036) \\ ( 2 : 安徽省林业科学研究院, 合肥 230031 )
}

摘 要: 水鸟是湿地生态系统健康的指示生物, 人类活动对其影响日益严重. 研究自然保护区内的水鸟生境适宜性变化 可以为湿地恢复提供帮助. 通过层次分析法确定水鸟生境影响因子的权重, 建立生境适宜性指数模型, 根据 TM 遥感影像 图和相关数据计算出安徽省升金湖国家级自然保护区 1986-2011 年 5个年份的水鸟生境适宜指数, 并结合 GIS 空间分 析生成的水鸟生境适宜性分级图, 分析升金湖建立保护区后水鸟生境适宜性变化. 结果表明: 升金湖地区在 1986 年建保 护区后的几年间水鸟生境适宜性相对平稳, 但是仍然有较为明显的下降; $1990 \mathrm{~s}$ 后期, 该地区水鸟生境适宜性开始显著恶 化, 一直持续到 2000 年之后才有小幅度的回升. 水鸟生境适宜性最好的区域由片状分散逐渐转变成小范围聚集, 适宜区 域也在由实验区和缓冲区向核心区迁移的过程中显著缩减. 本文还讨论了在研究中存在的不足, 并提出一些恢复水鸟生 境的建议.

关键词: 水鸟;生境适宜性指数;升金湖国家级自然保护区; 遥感影像; GIS

\section{Habitat suitability change of water birds in Shengjinhu National Nature Reserve, Anhui Province}

YANG $\mathrm{Li}^{1,2}$, DONG Bin ${ }^{1}$, WANG Qing ${ }^{1}$, SHENG Shuwei ${ }^{1}$, HAN Wenyan ${ }^{2}$, ZHAO Jun ${ }^{1}$, CHENG Mingwei ${ }^{2} \&$ YANG Shaowen ${ }^{1}$

(1: Graduate School of Anhui Agricultural University, Hefei 230036, P. R. China)

(2: Anhui Academy of Forestry, Hefei 230031, P. R. China)

Abstract: Water bird is an indicator of a healthy wetland ecosystem. It has been affected more and more by human activities recently. The research, which focuses on environmental suitability change of its habitat in the nature conservative area, may help restore the wetland to some extent. In this paper, we determined the proportion of each factor that may affect the habitat of water bird through the Analytic Hierarchy Process and established an index model for its habitat suitability. According to TM remote sensing images and historical data, we calculated the habitat suitability index of the Shengjinhu National Nature Reserve in five years, from 1986 to 2011. Besides, we analyzed the suitability change of its habitat after the establishment of the natural reserve, combined with the habitat suitability classification map using GIS spatial analysis. The results showed that its habitat suitability was relatively stable in the early years after the establishment of natural reserve in 1986, whereas an obvious decrease was also observed. The habitat suitability began to deteriorate significantly in the late 1990s. The situation lasted until the year 2000 , after when it was improved slightly. The districts which had the best habitat suitability were gradually changing from scattered plate-like area to aggregated small range. Suitable area was also obviously reduced during the migration from the experimental and buffer area to the core area. The most suitable areas gradually evolved into suitable areas, while regular suitable region was mainly composed of a suitable area to change, mini-suitable and not suitable for area also increased year by year. Moreover, we discussed imperfections of this research, and provided several suggestions on protecting and rebuilding the habitat suitability of water bird.

Keywords: Water bird; habitat suitability index; Shengjinhu National Nature Reserve;remote sensing image; GIS

* 安徽省国土资源厅科技项目(2012-K-24、2011-K-23、2013-K-10)、国家自然科学基金项目(41571101)、安徽农业大学 引进与稳定人才科研启动项目 (wd2011-07) 和安徽省高校省级自然科学研究项目 (KJ2012Z108) 联合资助. 2014-12-10收稿;2015-04-08收修改稿. 杨李(1984 ), 女, 硕士, 助理研究员; E-mail:366684591@ qq. com.

** 通信作者;E-mail:dbhy123@ sina. com. 
水鸟是指在生态上依赖湿地环境, 并在形态和行为上对湿地形成适应特征的鸟类, 是湿地野生动物中最具有 代表性的类群, 其物种多样性、种群丰富度和衍生指数变化反映湿地不同营养层次的变化, 且具有对环境灵敏的指 示功能, 一般认为水鸟是湿地生态系统健康的最佳指示生物, 也是其栖息湿地恢复程度的评价指标 ${ }^{[1-2]}$. 就水鸟而 言, 生境是指个体、种群或群落在其某一生活史阶段 (比如繁殖期、越冬期) 所占据的环境类型、进行各种生 命活动的场所 ${ }^{[3]}$. 水鸟的生境适宜性评价是指通过分析水鸟的生境要求与某地区环境的匹配情况来确定该 地区水鸟的生境适合度.

近些年来, 国内外利用遥感与 GIS 技术, 通过建立水鸟生境适宜性模型来监测和评估其生境质量的探 讨已经逐渐形成一种研究发展方向. Shealer 等通过量化黑燕鸥 (Chlidonias niger) 的生境特征, 对 2010 年美 国湿地进行适宜性排名, 其结论与运用遥感和实地调查 2 种评价方法得到的结果高度一致 ${ }^{[4]}$. Van Schmidt 等通过选择栖息地组成值,创建生境适宜性地图, 以确定 2011 年美洲鹤 (Grus americana) 的最佳栖息地 ${ }^{[5]}$. 邹丽丽等利用遥感影像的提取结合逻辑斯蒂回归模型对比 2003 和 2009 年的路科水鸟栖息地适宜性 ${ }^{[6]}$. 董 张玉等按照不同指标因子的等级划分得到盘锦湿地水禽栖息地 2010 年的适宜性评价图 ${ }^{[7]}$. 这些研究在近 些年来的湿地水鸟的生境评价上进行了很好的探讨, 如果通过跟踪长期数据来分析湿地的动态变化, 可以 达到预测该地区乌类生境演变和合理规划未来修复工作的目的. 本文以升金湖国家级自然保护区为研究区 域, 以遥感与 GIS 技术为支持, 通过建立水鸟生境适宜性评价模型, 计算保护区 25 年间的水鸟生境适宜指 数, 结合生成的生境适宜性分级图, 分析升金湖建立保护区后水鸟生境适宜性变化, 并提出了一些保护和修 复水鸟生境的建议.

\section{1 研究区与研究方法}

\section{1 研究区概况}

升金湖国家级自然保护区 $\left(30^{\circ} 15^{\prime} \sim 30^{\circ} 30^{\prime} \mathrm{N}, 116^{\circ} 55^{\prime} \sim 117^{\circ} 15^{\prime} \mathrm{E}\right)$ 位于东至县与贵池区交界处, 全境以 升金湖为中心, 沿岸分别向外延伸 $2.5 \mathrm{~km}$ 左右, 海拔平均为 $11 \mathrm{~m}$. 保护区总面积为 $33340 \mathrm{hm}^{2}$, 其中核心区 $10150 \mathrm{hm}^{2}$, 占保护区总面积的 $30.4 \%$; 缓冲区 $10300 \mathrm{hm}^{2}$, 占保护区总面积的 $30.9 \%$; 实验区 $12890 \mathrm{hm}^{2}$, 占 保护区总面积的 $38.7 \%$.

升金湖国家级自然保护区位于亚太地区候鸟迁徙沿线,湖滩广阔且饵料较足; 迁徙水鸟每年 10 月初陆 续迁到升金湖, 次年 4 月末迁离. 该保护区 1995 年加人 “中国人与生物圈自然保护区网络”,2002 年加人 “东 北亚鹤类网络保护区”,2005 年加人 “东亚一澳大利西亚涉禽保护区网络”, 是长江中下游湿地保护网络成 员, 是中国和亚洲重要湿地 ${ }^{[8]}$.

保护区内人口约 2 万, 以农业为主、林业为辅, 主要种植水稻、棉花、油菜等. 湖区周边低丘主要有杉木、 马尾松等树种, 还有一部分天然阔叶林和以梨、桃为主的人工经果林. 升金湖有 $1000 \mathrm{hm}^{2}$ 用于人工养鱼. 由 于保护区内大多数为植食性水鸟, 包括鸿雁、小天鹅和白头鹤等 (统称为食块茎的鸟类), 沉水植物为其提供 块茎 (如苦草块茎等), 而大量的鱼类饲养使得沉水植物分布面积减少 (上湖已很难发现苦草 ${ }^{[9]}$ ), 严重影响 湿地生态环境, 有碍珍稀鸟类的保护 ${ }^{[10-11]}$.

\section{2 研究材料}

根据发展历史: 1986 年经安徽省人民政府批准建立升金湖自然保护区, 1997 年晋升为国家级自然保护 区, 2000 年成立升金湖国家级自然保护区管理局; 结合升金湖地区的建设: 1994-1997 年升金湖大桥修建, 2004 年沿江高速开通和 2011 年升金湖上湖的生态修复工程开始, 并考虑到保护区候鸟习性和越冬情况, 本 文最终选择采用升金湖湿地 1986、1995、2000、2004、2011 年 11 月的 TM 遥感影像进行解译.

根据本地区地理特征和影像质量, 结合升金湖湿地 1:10000 地形图和功能分区图, 运用 ERDAS 软件, 进 行波段融合、几何校正、图像增强和裁剪等数据预处理. 参考中华人民共和国土地管理行业标准县级土地利 用总体规划编制规程、《土地利用现状分类》及相关文献, 结合研究区实际情况, 通过监督分类将升金湖湿地 的土地利用现状分为 8 大类: 建设用地、草地、耕地、林地、水域、未利用地、交通用地、园地, 分类结果经检验 符合分类标准, Kappa 系数为 $93 \%$, 分类精度较高, 可以作为下一步评价因子的评价基础 ${ }^{[12-13]}$. 再运用 ArcGIS 10.2 的统计功能对各地类面积进行统计, 得出各地类面积并计算出所占比例. 


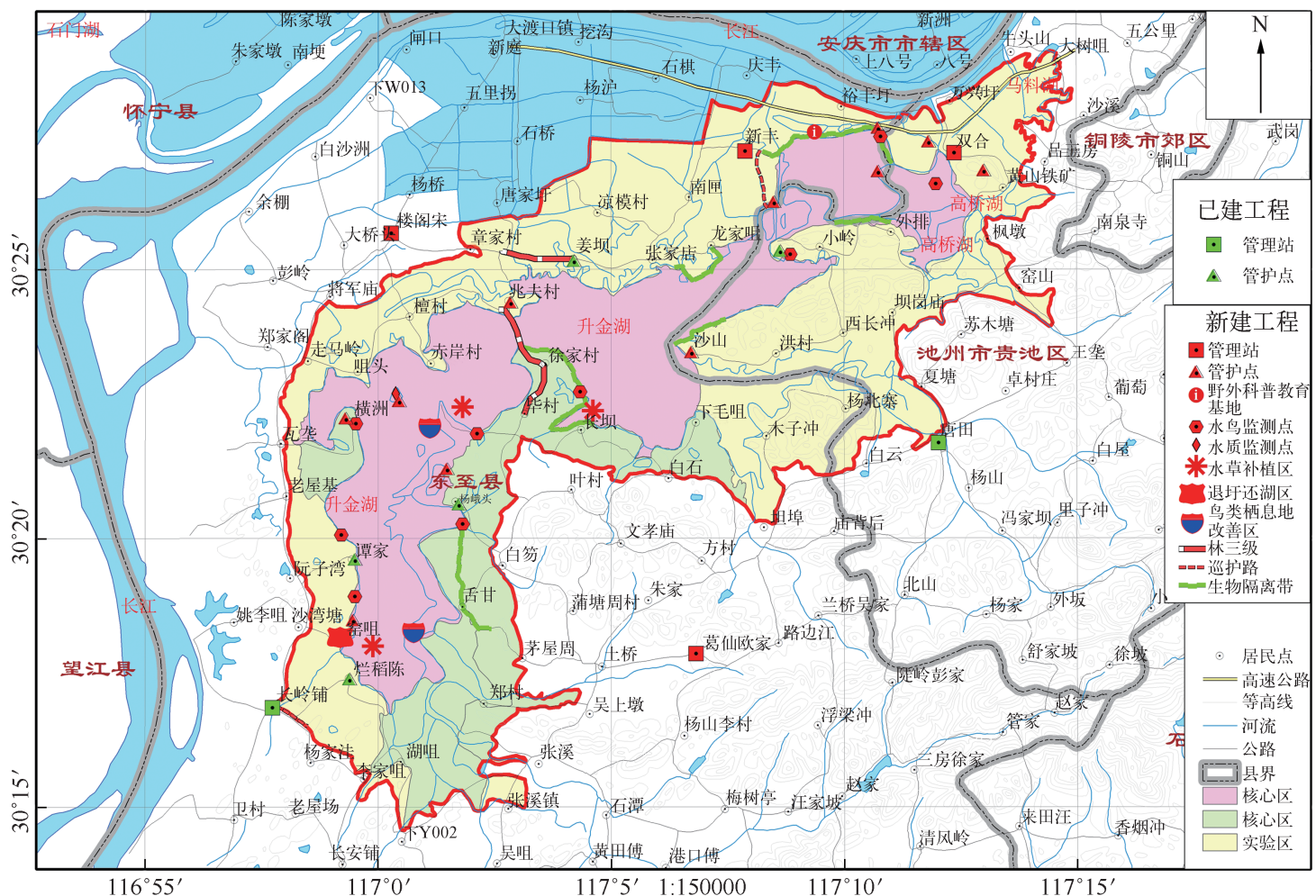

图 1 研究区域地理位置及分区

Fig. 1 Geographical location and zonal-sketch of the research area

本文各土地利用类型对应的水鸟生境适宜性优越排序为: 125 沼泽地 (未利用地) > 116 内陆滩涂 (水 域) $>043$ 其他草地 (草地) >011 水田 (耕地) >013 旱田 (耕地) >021 果园 (园地) >031 有林地 (林地) > 111 河流水面 (水域) $>112$ 湖泊水面 (水域) $>072$ 农村宅基地(建设用地) $>102$ 公路用地(交通用地).

本研究区域中的湿地包含 125 沼泽地、116 内陆滩涂、043 其他草地、011 水田、111 河流水面和 112 湖泊 水面.

\section{3 生境评价因子和评价模型}

1.3.1 评价因子的选取 通过分析升金湖国家级自然保护区水鸟的主要种类, 进而确定主要鸟类的生境需求, 根 据其特点以及资料的可获取性, 选取动物生存的基本需求一一食物条件、水条件、隐蔽条件及针对野生动物选取 的干扰条件这 4 个评价因子, 即 4 个准则层指标. 然后进行各项因子的细化, 并通过层次分析法确立各因子的 权重.

本文运用 Yaahp 层次分析法软件对水鸟生境适宜性评价因子的权重进行确定, Yaahp 层次分析软件原 理主要是专家打分, 根据指标之间重要性的对比, 选取相关的专家, 通过软件计算得出权重. 再运用 Yaahp 层次分析软件计算得出各类指标权重, 判断矩阵均采用群体判断的方法构造, 结果分别构造 A-B、B $-\mathrm{C}$ 的 判断矩阵.

首先对准则层的权重进行打分确定, 其中食物条件和干扰条件对野生鸟类的生境适宜性影响较大, 水 条件和隐蔽条件的影响次之. 其次确定这 4 个指标层下的子指标权重. 为减小权重计算时两极分化的拉大, 本文在每个指标层下选取 3 个最具影响性的评价因子, 同时确保其判断取值在 $1 \sim 4$ 之间, 即同等重要 明 显重要. 升金湖保护区多为草食性和杂食性水鸟 ${ }^{[14]}$, 以沉水植物为基础的食物链被鱼类养殖业破坏明显, 所 以在食物条件这一准则层下, 水产品产量对水鸟的影响最大; 水旱灾受灾面积直接影响滩涂面积和环境, 虽 然其对水鸟食物来源的影响性不如水产品产量因子大, 但是比起粮食产量要稍微重要. 在水条件的准则层 
下, 水面积与水位是较为直观的影响因子, 而降水量的反映情况并不如以上 2 个因子显著. 隐蔽条件主要通 过土地利用情况来反映: 根据升金湖地区水鸟的种类特征和其对应的活动特点, 草地的隐蔽性影响要明显 高于未利用地; 本保护区内林地主要集中在东南部的低山丘陵区, 考虑到水鸟在该林地中活动较少, 且本文 主要评价水鸟越冬期生境, 因此隐蔽条件中林地的重要性相对较小. 在升金湖保护区内, 对野生动物的干扰 主要来源于人类活动, 在这一准则层中, 建设用地 (区内永久性建筑的面积) 的影响占据决定性因素, 且具有 长期影响性, 人口数量也是较为显著的指标, 交通用地面积属于间接反映人类活动的指标, 故其重要性相对 低些. 最后进行层次总排序, 总一致性比例 $C R=0.0688$, 小于规定的 0.1 , 该水鸟生境适宜性评价指标层次 总排序具有满意的一致性. 评价指标体系及权重见表 1 .

表 1 升金湖国家级自然保护区水鸟生境适宜性评价因子权重

Tab. 1 Evaluation factors' weight of the water birds' habitat suitability in Shengjinhu National Nature Reserve

\begin{tabular}{|c|c|c|c|c|c|c|}
\hline \multirow{2}{*}{ 目标层 $A$} & \multicolumn{2}{|c|}{ 准则层 $B$} & \multicolumn{2}{|c|}{ 指标层 $C$} & \multirow{2}{*}{ 总权重 } & \multirow{2}{*}{ 总排序 } \\
\hline & 准则名称 & 权重 & 指标名称 & 权重 & & \\
\hline \multirow{12}{*}{$\begin{array}{l}\text { 升金湖国家级自然保护区 } \\
\text { 水鸟生境适宜性评价 }\end{array}$} & \multirow[t]{3}{*}{ 食物条件 $B_{1}$} & \multirow[t]{3}{*}{0.2911} & 水产品产量 $C_{11}$ & 0.6144 & 0.1788 & 1 \\
\hline & & & 水旱灾成灾面积 $C_{12}$ & 0.2684 & 0.0781 & 6 \\
\hline & & & 粮食产量 $C_{13}$ & 0.1172 & 0.0341 & 11 \\
\hline & \multirow[t]{3}{*}{ 水条件 $B_{2}$} & \multirow[t]{3}{*}{0.2447} & 水面积 $C_{21}$ & 0.5938 & 0.1453 & 3 \\
\hline & & & 降水量 $C_{22}$ & 0.1569 & 0.0384 & 10 \\
\hline & & & 水位 $C_{23}$ & 0.2493 & 0.0610 & 7 \\
\hline & \multirow[t]{3}{*}{ 隐蔽条件 $B_{3}$} & \multirow[t]{3}{*}{0.1731} & 林地面积 $C_{31}$ & 0.3195 & 0.0553 & 8 \\
\hline & & & 草地面积 $C_{32}$ & 0.5586 & 0.0967 & 5 \\
\hline & & & 未利用地面积 $C_{33}$ & 0.1219 & 0.0211 & 12 \\
\hline & \multirow[t]{3}{*}{ 干扰条件 $B_{4}$} & \multirow[t]{3}{*}{0.2911} & 人口数量 $C_{41}$ & 0.3326 & 0.0968 & 4 \\
\hline & & & 建设用地面积 $C_{42}$ & 0.5278 & 0.1536 & 2 \\
\hline & & & 交通用地面积 $C_{43}$ & 0.1395 & 0.0406 & 9 \\
\hline
\end{tabular}

1.3.2 数据归一化处理 把各项细化因子的实测和统计数据进行归一化处理, 将其值统一在 $0 \sim 1$ 范围内, 以消除量纲差异的影响.

不同的因子采取的归一化方法不同,具体方法如下:

$$
\begin{aligned}
& x(i, j)=x^{*}(i, j) / x_{\text {max }}(j)(\text { 值越大, 适宜性越好的指标因子 }) \\
& x(i, j)=x_{\text {min }}(j) / x^{*}(i, j)(\text { 值越小, 适宜性越好的指标因子 })
\end{aligned}
$$

式中, $(i, j)$ 为指标特征值归一化的序列, $x^{*}(i, j)$ 为第 $i$ 个样本的第 $j$ 个指标, $x_{\text {max }}(j)$ 为第 $j$ 个指标的最大值, $x_{\min }(j)$ 为第 $j$ 个指标的最小值.

其中, 水产品产量、水旱灾成灾面积、人口数量、建设用地面积和交通用地面积是对生境适宜性为负影 响的因子, 即值越小适宜性越好, 其余因子为正影响因子, 即值越大适宜性越好.

1.3 .3 评价模型建立 根据升金湖保护区水鸟生境适宜性评价因子以及各因子的权重, 采用模糊赋值求积 法 $^{[15]}$ 建立该保护区的水鸟生境适宜性评价模型:

$$
H S I_{\text {总 }}=A \cdot G=\sum_{i=1}^{n}\left(A_{i} \cdot G_{i}\right) \times 100
$$

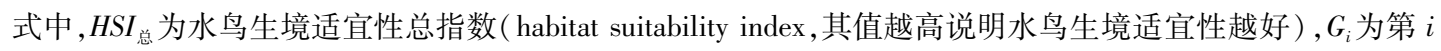
个生境适宜性评价因子的值, $A_{i}$ 为评价因子 $G_{i}$ 的权重. 本模型中乘以 100 为使评价结果便于运用.

\section{4 生境适宜性分布图}

1.4.1 选取评估点评分 在保护区中设定评估点时, 参考曹铭昌等 ${ }^{[16]}$ 、孔博等 ${ }^{[17]}$ 的保护区面积和选点的比 例, 本文在核心区、缓冲区和实验区各均匀选取 10 个点, 记录坐标值. 
根据水鸟生活习性资料和野外实地观测结果, 设置每个生境适宜性评价因子的评价标准 ${ }^{[18-19]}$, 运用模 糊赋值法分别计算每个点的 $H S I$ :

$$
H S I_{\text {点 }}=\left(V_{1} \cdot V_{2} \cdot V_{3} \cdot V_{4}\right)^{1 / 4}
$$

1.4.2 生成适宜性分级图 按年份把每个评估点的 HSI 值和对应坐标在 ArcGIS 10.2 空间分析中运用克里 克插值法进行叠加, 生成相应年份的水鸟生境适宜性分级图, 并通过软件的统计功能计算出各级适宜性面

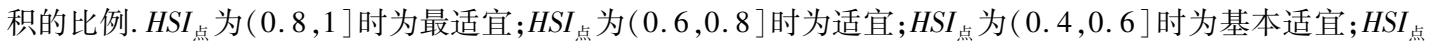

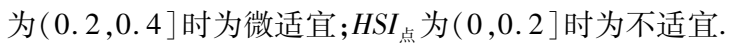

表 2 各生境适宜性评价因子的评价标准

Tab. 2 Evaluation criteria of the habitat suitability evaluation factors

\begin{tabular}{llllll}
\hline 评价因子 & 最适宜 $(1)$ & 适宜 $(0.75)$ & 基本适宜 $(0.5)$ & 微适宜 $(0.25)$ & 不适宜 $(0)$ \\
\hline 食物条件 $V_{1}$ & 湖岸、河岸、水田 & 旱地、草滩 & 园地 & 林地 & $\begin{array}{l}\text { 湖心区域、人工 } \\
\text { 表面 }\end{array}$ \\
& & & & & \\
水条件 $V_{2}$ & 距离水域、水田 & 距离水域、水田 & 距离水域、水田 & 距离水域、水田 & 距离水域、水田 \\
& $100 \mathrm{~m}$ 以内 & $100 \mathrm{~m}$ 以上、 $200 \mathrm{~m}$ & $200 \mathrm{~m}$ 以上、 $500 \mathrm{~m}$ & $500 \mathrm{~m}$ 以上、 $1 \mathrm{~km}$ & $1 \mathrm{km以上}$ \\
& & 以内 & 以内 & 以内 & \\
隐蔽条件 $V_{3}$ & 芦苇丛、乔木林 & 灌木林、耕地 & 高覆盖草滩 & 低覆盖草滩 & 裸地、湖心区域、 \\
& & & & & 人工表面 \\
干扰条件 $V_{4}$ & 距离道路、居民点 & 距离道路、居民点 & 距离道路、居民点 & 距离道路、居民点 & 距离道路、居民点 \\
& $2 \mathrm{~km}$ 以上 & $1.5 \mathrm{~km}$ 以上、2 $\mathrm{km}$ & $1 \mathrm{~km}$ 以上、1.5 $\mathrm{km}$ & $500 \mathrm{~m}$ 以上、1 $\mathrm{km}$ & $500 \mathrm{~m}$ 以内 \\
& & 以内 & 以内 & 以内 & \\
\hline
\end{tabular}

\section{2 结果与分析}

\section{1 升金湖国家级自然保护区土地利用类型结构变化}

升金湖国家级自然保护区 1986-2011 年耕地面积所占比例最大,其次是水域(图 2). 保护区 25 年间建设 用地、未利用地和交通用地面积的增长速度最高, 达到 300\% 以上; 耕地减少的面积最大, 减少了约 $6000 \mathrm{hm}^{2}$; 水域、草地和林地面积一直保持小范围的波动.

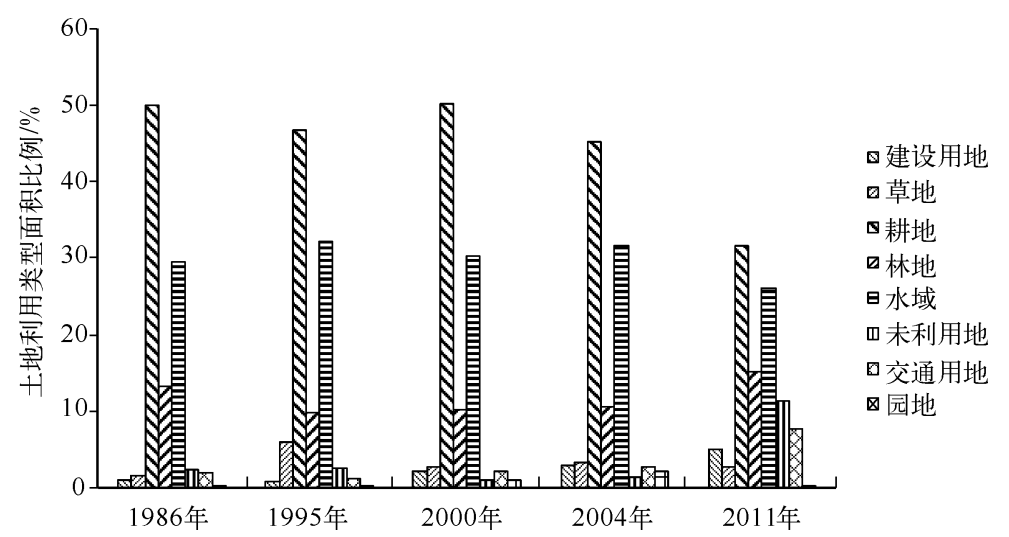

图 2 升金湖国家级自然保护区土地利用类型结构

Fig. 2 Structure of land use types in Shengjinhu National Nature Reserve

\section{2 生境适宜性总指数变化}

经计算得出升金湖国家级自然保护区 1986- 2011 年水鸟生境适宜性总指数分别为 $83.8030 、 82.5438 、 73.4155$ 、 75.7750 和 74.5783. 升金湖地区在 1986 年建保护区后的几年间水鸟生境适宜性相对平稳, 但是仍然 


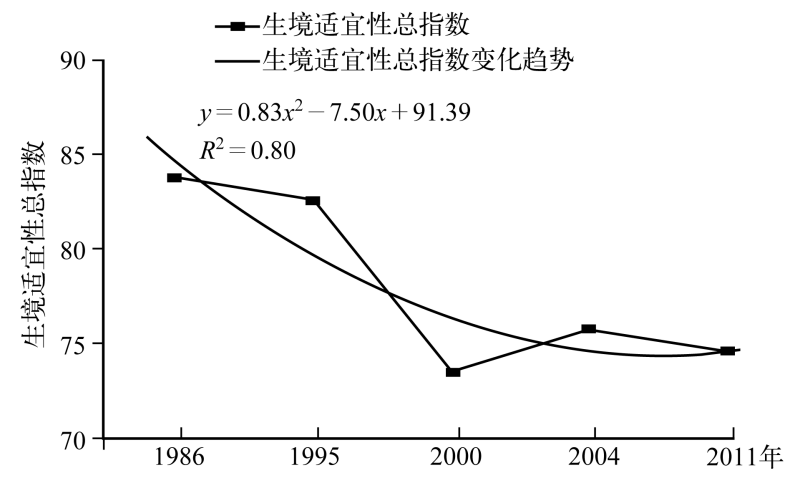

图 3 1986-2011 年升金湖国家级自然保护区 水鸟生境适宜性总指数变化

Fig. 3 Integrated index of the water birds' habitat suitability in Shengjinhu National Nature Reserve during 1986-2011

区域转化而来, 微适宜和不适宜区域的面积也在逐年上升.
有较为明显的下降; $1990 \mathrm{~s}$ 后期, 水鸟生 境适宜性开始显著恶化, 一直持续到 2000 年之后才有小幅度的回升, 而且回 升并不平稳,会出现小范围的波动.

总生境适宜度变化趋势线为: $y=0.83 x^{2}-$ $7.50 x+91.39\left(R^{2}=0.80\right)$, 较为接近于 1 , 可 以大致反映出升金湖国家级自然保护区 25 年间水鸟生境适宜度的变化趋势 (图 3 ).

\section{3 水鸟生境适宜性分级图及其变化趋势}

经 ArcGIS 软件生成图 4, 可以看出该区 内水鸟生境适宜性最好的区域由片状分散逐 渐转变成小范围聚集, 适宜区域也在由实验 区和缓冲区向核心区迁移的过程中显著缩 减. 结合图 5 可以看到, 最适宜区域逐渐演变 成适宜区域, 而基本适宜区域也主要由适宜
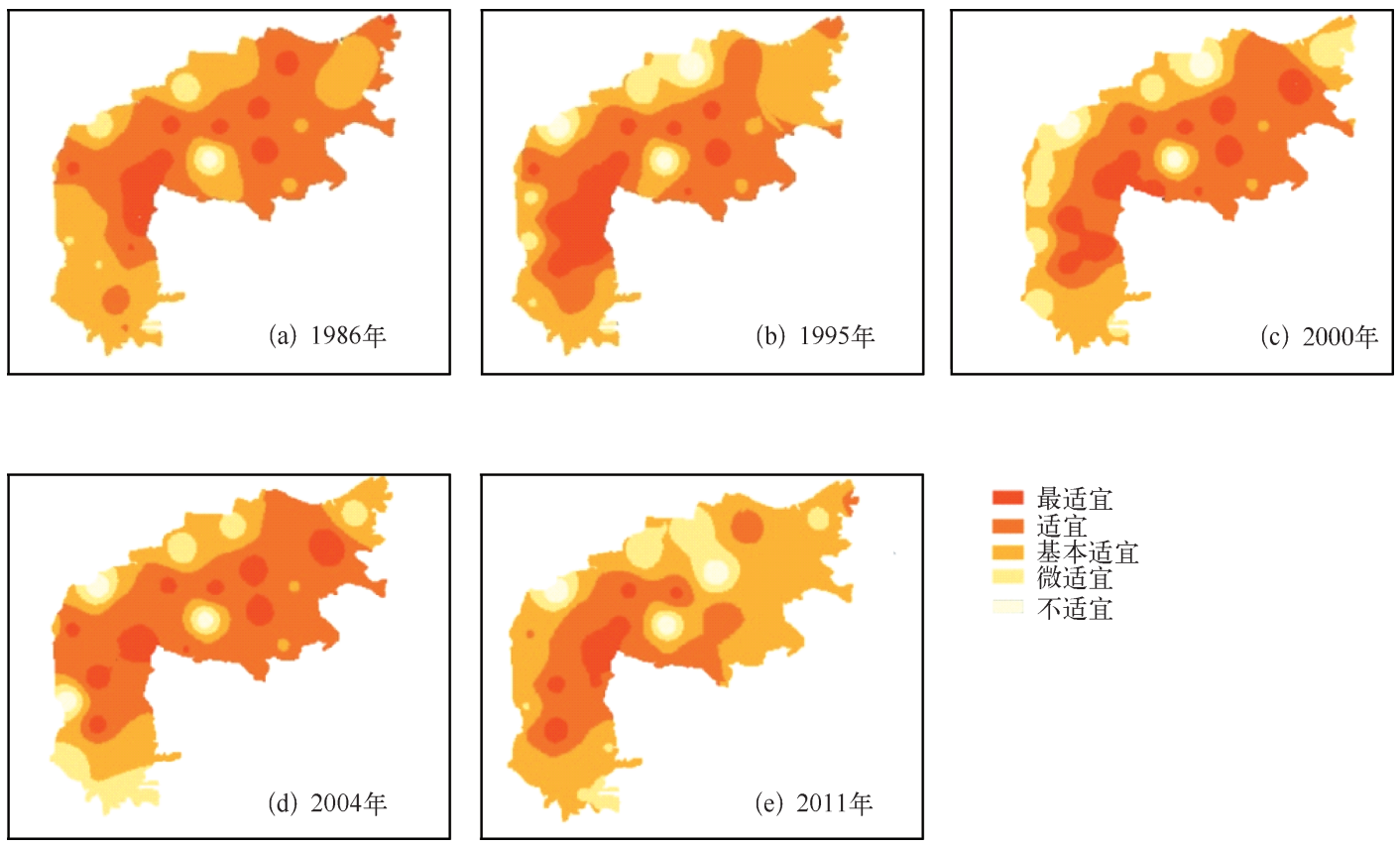

图 4 1986-2011 年升金湖国家级自然保护区水鸟生境适宜性分级

Fig. 4 Classification of the wetland birds' habitat suitability in Shengjinhu National Nature Reserve during 1986-2011

\section{4 结论与分析}

升金湖国家级自然保护区共发现水鸟 66 种,其中 2008/2009 年冬季发现 62 种,共 71423 只,2011/2012 年发现 48 种, 共 83537 只, 水鸟多样性下降, 但是优势物种的数量显著升高. 选取保护区内 5 种重要水 鸟调查数据进行对比 (表 3 ), 其中濒危鸟类东方白鹳属杂食性水鸟, 其数量呈上升趋势; 小天鹅和鸿雁 属易危鸟类, 数量均下降; 豆雁和白额雁属保护区内鸭科优势物种, 为数量最多的 2 类水鸟, 并且呈逐 年上升趋势. 经分析发现, 主要活动范围在最适宜和适宜区域的水鸟数量均有上升, 而分布在经适宜 
区域演变而来的基本适宜区域的水鸟数量呈显著下降趋 势, 由此也可印证水鸟生境适宜性分级图的变化趋势是 正确的.

升金湖以升金湖大桥为中线, 东北是下湖, 西南是上 湖,上下湖中间为中湖. 在这 3 片水域中, 中湖水位较深, 湖 水透明度较低,水生植物集中在沿岸的浅滩区域生长; 而下 湖湖面较小, 中湖、下湖的水生植物资源均远少于上湖. 此 外, 相比于上湖, 中湖和下湖有大量围网, 在水产养殖力度 方面大于上湖 (造成这 2 个湖区的水生植物资源的破坏力 度大于上湖), 导致上湖的湿地植物群落的生物多样性高于 中湖和下湖. 在有资料记载的文献中发现, 自 1970s 以来,升 金湖水生植物优势种由沉水植物向浮水植物演变, 沉水植 物优势种竹叶眼子菜与苦草在升金湖水生植物中所占比例 逐渐减少 ${ }^{[20]}$,在近年来的调查中几近消失, 这些对水鸟生境 的变化造成显著影响.

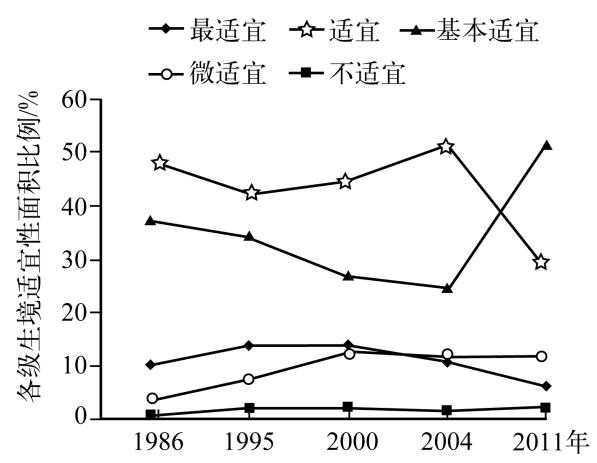

图 5 1986-2011 年升金湖国家级自然保护区 各级生境适宜性面积比例

Fig. 5 Percentage of each classification habitat suitability's area in Shengjinhu National Nature Reserve during $1986-2011$

表 3 升金湖国家级自然保护区 5 种重要水鸟的 2 期调查数据

Tab. 3 Two survey data of the five important water birds in Shengjinhu National Nature Reserve

\begin{tabular}{|c|c|c|c|c|c|}
\hline 种类 & 濒危等级 & 食性 & 主要活动范围 & $\begin{array}{c}2008 / 2009 \text { 年统计 } \\
\text { 数量 }\end{array}$ & $\begin{array}{c}2011 / 2012 \text { 年统计 } \\
\text { 数量 }\end{array}$ \\
\hline 东方白鹳 & 濒危 & $\begin{array}{l}\text { 主要采食植物种子、叶、 } \\
\text { 草根、苔藓和少量的鱼类 }\end{array}$ & $\begin{array}{l}\text { 上湖的南部和下湖的东 } \\
\text { 北部 }\end{array}$ & 72 & 251 \\
\hline 小天鹅 & 易危 & $\begin{array}{l}\text { 主要取食水生植物,包括 } \\
\text { 叶子、种子、根及块茎 }\end{array}$ & 广泛分布于整个湖区 & 1788 & 1152 \\
\hline 鸿雁 & 易危 & 主要以苦草块茎为食物 & 下湖北部和西南部 & 1179 & 159 \\
\hline 豆雁 & 低危 & 主要以苔草为食 & $\begin{array}{l}\text { 全湖分布, 主要为上湖南 } \\
\text { 部和下湖东北部 }\end{array}$ & 41457 & 52165 \\
\hline 白额雁 & 低危 & 主要以苔草为食 & $\begin{array}{l}\text { 上湖南部和下湖东北部 } \\
\text { 苔草滩地 }\end{array}$ & 11677 & 18600 \\
\hline
\end{tabular}

\section{3 讨论}

水鸟生境最适宜区域主要分布于滨海地区的大片 芦苇湿地内部以及河流、湖泊等水源与食物比较充足的 地区, 其地势平坦、水源充足、有大面积的芦苇沼泽湿地 及河滩地, 区域内人口稀少, 很少有村庄及道路设施干 扰, 为水禽提供了良好的受食、隐蔽和繁殖场所 ${ }^{[7]}$. 本研 究通过建立 $H S I$ 模型, 从保护区水鸟生境适宜性总指数 和分级分布 2 个方面进行评价, 总体可以反映升金湖国 家级自然保护区建区 25 年内的变化情况, 但是也存在 一些局限性. 首先, 在做适宜性评价时没有考虑到鸟类 的飞行能力,这就忽略了研究对象对生境的忠诚度和斑 块连续性的影响, 使生境适宜性指数偏高. 其次, 在湖区 水质变化和水产养殖业蔓延的情况下, 因没有对应 5 期 的权威调查结果, 未结合湿地植物生物量和底栖生物种 类的数据来分析给不同食性水鸟带来的影响. 从前些年

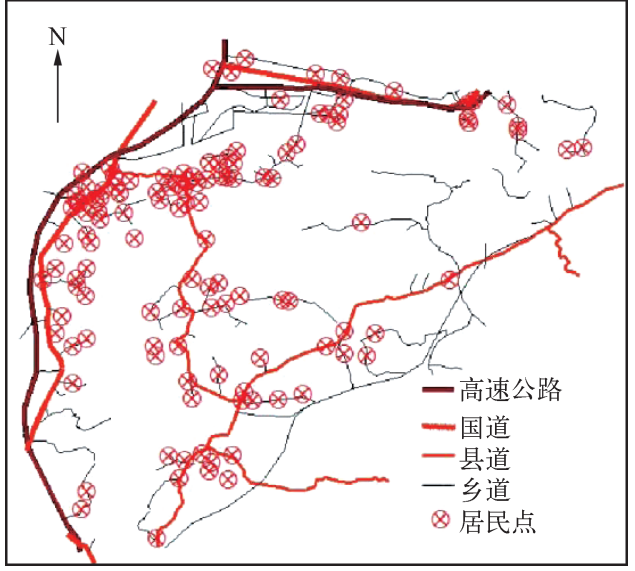

图 62014 年升金湖国家级自然保护区 主要道路、居民点分布示意

Fig. 6 Distribution of the main roads and housing estate of Shengjinhu National Nature Reserve in 2014 
开始, 国内重视相关领域的研究, 已有可利用的有效数据, 在今后的研究中可以通过进一步收集多方面的生 境数据来修正评价模型, 做更深人的分析, 或结合当前景观现状图和水鸟分布图预测该区域未来各类重要 水鸟的生境适宜性变化. 现就研究中发现的问题提出以下解决方案供保护区的管理和修复工作参考:

1 ) 在保护区的西侧和北侧边界是高速公路和国道路段, 其中沿江高速有 $13 \mathrm{~km}$ 在保护区的范围内, 更 有县道南北贯穿核心区 (图 6), 在沿江地区经济越发达、交通越繁忙的时期, 车辆的噪声和灯光对鸟类等野 生动物的生境破坏都是非常严重的. 建议在距离核心区 $2 \mathrm{~km}$ 或者位于保护区范围内的高速路段双向双侧安 装隔音不透明墙板, 在国道路段靠保护区侧设置隔离铁丝网栏, 并把核心区和大部分缓冲区的居民集中 迁出.

2) 在保护区土地利用的变化中耕地面积大量减少, 但是根据土地利用转移分析, 减少的耕地并不都转 化为林地和草地, 交通用地和建筑用地上升比例也非常高. 由于耕地中化肥和农药的使用量逐年上升, 加剧 了土壤的退化和水体的富营养化. 退耕还林、退耕还草和封山育林可以保持水土、抵御洪涝灾害, 提高水鸟 生境质量,增加水鸟的食物来源和活动空间.

\section{4 参考文献}

[ 1 ] Neckles HA, Dionne M, Burdick DM et al. A monitoring protocol to assess tidal restoration of saltmarshes on local land regional scales. Restoration Ecology, 2002, 10: 556-563.

[ 2 ] Konisky RA, Burdick DM, Dionne MD et al. A regional assessment of saltmarsh restoration and monitoring in the Gulf of Maine. Restoration Ecology, 2006, 14: 516-525.

[ 3 ] 江红星,刘春悦,侯韵秋等. $3 \mathrm{~S}$ 技术在鸟类栖息地研究中的应用. 林业科学,2010,46(7): 155-163.

[ 4 ] Shealer DA, Alexander MJ. Use of aerial imagery to assess habitat suitability and predict site occupancy for a declining wetland-dependent bird. Wetlands Ecology and Management, 2013, 21 (4) : 289-296.

[ 5 ] Van Schmidt, Nathan D, Barzen JA et al. Refining reintroduction of whooping cranes with habitat use and suitability analysis. Journal of Wildlife Management, 2014, 78 (8) : 1404-1414.

[ 6 ] 邹丽丽,陈晓翔,何 荣等. 基于逻辑斯蒂回归模型的路科水鸟栖息地适宜性评价. 生态学报, 2012,32(12): 3722-3728.

[ 7 ] 董张玉, 刘殿伟, 王宗明等. 遥感与 GIS 支持下的盘锦湿地水禽栖息地适宜性评价. 生态学报, 2014, 34 (6): 1503-1511.

[ 8 ] 升金湖国家级自然保护区简介. 安徽林业科技,2004,(1):45.

[ 9 ] Zhang Y, Cao L, Barter M et al. Changing distribution and abundance of Swan Goose Ansercygnoides in the Yangtze River floodplain: the likely loss of a very important wintering site. Bird Conservation International, 2011, 21 (1) : 36-48.

[10］张淑霞,董云仙, 夏 峰. 湖泊生态系统的水鸟监测意义. 湖泊科学, 2011, 23 (2): 155-162. DOI 10. 18307/ 2011. 0201 .

[11] Roomen M, Koffijberg K, Noordhuis R et al. Longterm waterbird monitoring in the Netherlands: a tool for policy and management. In: Boere G, Galbraith C, Stroud D eds. Waterbirds around the world. Edinburgh: The Stationery Office, 2006: $463-470$.

[12] 李 崟, 董 斌, 孙 力等. 基于 TM 像元的湿地土地利用生态风险评价研究. 水土保持研究, 2014, 21 (4): 114-119.

[13] 钱国英, 张长勤, 董 斌等. 基于遥感与系统动力学模型的土地利用/覆被变化研究. 遥感信息, 2014,29(1): 44-50.

[14] 宫 蕾,张黎黎, 周立志等. 长江中下游安庆沿江湖泊湿地夏季鸟类多样性调查. 湖泊科学, 2013,25(6):872-882. DOI 10. 18307/2013.0611.

[15] 刘丙万, 顾 丽, 张 博等. 内蒙古达麥湖地区蒙原羚生境适宜度评价. 生态学杂志, 2012,31(10):2568-2572.

[16] 曹铭昌, 刘高焕, 单 凯等. 基于多尺度的丹顶鹤生境适宜性评价. 生物多样性,2010,18(3):283-291.

[17] 孔 博, 张树清, 张 柏等. 遥感和 GIS 技术的水禽栖息地适宜性评价中的应用. 遥感学报, 2008, 12 (6): 1001-1009.

[18］王志强,陈志超, 郝成元. 基于 HSI 模型的扎龙国家级自然保护区丹顶鹤繁殖生境适宜性评价. 湿地科学, 2009,7 (3) : 197-201.

[19] 朱丽娟,刘红玉. 挠力河流域丹顶鹤繁殖期生境景观连接度分析. 生态与农村环境学报,2008,24(2):12-16.

[20］马淑勇. 升金湖湿地维管植物群落结构研究 [ 学位论文].合肥:安徽大学,2011. 